\title{
Effect of different digestible isoleucine/lysine ratios for broiler chickens
}

\author{
Fernando de Castro Tavernari ${ }^{1}$, Guilherme Rodrigues Lelis ${ }^{2}$, Paulo Roberto de Oliveira \\ Carneiro $^{2}$, Rodolfo Alves Vieira ${ }^{2}$, Richard Costa Polveiro ${ }^{3}$, Jorge Armando Prada Luengas ${ }^{2}$, \\ Horacio Santiago Rostagno², Luiz Fernando Teixeira Albino ${ }^{2}$
}

\footnotetext{
${ }^{1}$ Embrapa Suínos e Aves.

2 Departamento de Zootecnia da Universidade Federal de Viçosa.

3 Departamento de Veterinária da Universidade Federal de Viçosa.
}

\begin{abstract}
Two experiments were conducted to evaluate different digestible isoleucine/lysine ratios on diets for broiler chickens in the starter ( 7 to 21 days) and finishing (30 to 43 days) phases. For the tests, the experimental design was of randomized blocks with seven treatments (six different digestible isoleucine/lysine ratios and a control treatment) and eight repetitions of 25 and 20 birds (COBB males) per experimental unit in the starter and finishing phases, respectively. The diets met the requirements, except for isoleucine and lysine. To avoid excess lysine in the experimental diets, the digestible lysine content was calculated to be $87 \%$ and $89 \%$ of the recommended for the starter and finishing phases, respectively. The control treatment was adequate in lysine and isoleucine. Feed intake, weight gain, feed conversion and carcass yield in the two phases were evaluated. There was quadratic effect of different ratios on feed intake in the finishing phase and on weight gain and feed conversion rate in both phases. There was quadratic effect on breast meat yield and breast fillets in the starter phase, but there was no significant effect on carcass yield in the finishing phase. The digestible isoleucine/lysine ratio recommended for broilers in the starter phase ( 7 to 21 days) is $66 \%$ and for the finishing phase (30 to 43 days), it is $68 \%$.
\end{abstract}

Key Words: isoleucine, lysine, ratio, requirement

\section{Introduction}

The accurate knowledge of the nutritional requirements of essential amino acids and the nutritional composition of raw materials is essential for the correct balancing of diets and, in light of this, the constant update of the ideal protein profile is indispensable.

In the ideal protein, lysine is viewed as a reference to the other essential amino acids, and several studies have been conducted with the first three limiting amino acids to broiler chickens. Isoleucine is one of the limiting amino acids in diets with low protein for broiler chickens, and few studies have been conducted on the digestible isoleucine/ lysine ratio (Park \& Austic, 2000).

Several institutions related to research, in Brazil and around the world, perform experiments for the determination of nutritional requirement of birds; however, because of the differences in methodology, genetic variance and ambience, it is possible to observe different requirement values in the literature.

According to Baker et al. (2002), the complexity to establish accurate ratios for amino acids lies in the possibilities of response variables to be utilized (such as weight gain and feed conversion) and the statistical analyses that may be conducted, in which the quadratic one is known for overestimating the ratios, whereas the linear response plateau (LRP), for underestimating them. These authors have utilized the quadratic one as the plateau and showed it as a possibility to the determination of amino acid ratios, once the values achieved were close to $90 \%$ of the values obtained with the quadratic analysis. According to Leclercq (1998a) the lack of knowledge of the requirements of non-essential amino acids is also a factor that affects the determination of essential amino acid ratios.

In many studies, the only criterion utilized for the determination of the requirement or the ratio between amino acids is weight gain, which can lead to an underestimate of requirements, once this parameter usually presents the lowest values, when compared with feed conversion, breast yield and abdominal fat (Leclercq, 1998b).

Thus, the objective of this study was to evaluate the digestible isoleucine/lysine ratios in the diet on performance and carcass yield of male COBB broilers in the period from 7 to 21 and 30 to 42 days of age. 


\section{Material and Methods}

Two experiments were conducted to determine the digestible isoleucine/lysine for male COBB 500 broilers in the phases from 7 to 21 days and 30 to 43 days. In the starter phase, the experimental design lasted 14 days ( 7 to 21 days of age), in which diets were supplied ad libitum. The experimental design was in completely randomized blocks, with seven treatments and eight replicates of 25 birds per experimental unit. Six different digestible isoleucine/lysine ratios (58.0; 61.5; 65.0; 68.5; 72.0 and 75.5\%) were assessed. Diets were formulated to meet the requirements according to Rostagno et al. (2005), except for isoleucine and lysine. In order to avoid excess of lysine, the digestible lysine value of experimental diets was calculated to meet $87 \%$ of the requirements according to Rostagno et al. (2005) (1.000\%). A positive control $(\mathrm{C}+$ ) treatment adequate in lysine $(1.146 \%)$ and isoleucine (0.755\%) was included in the experimental design.

In the finishing phase, the experimental period lasted 13 days (30 to 43 days of age), when diets were supplied ad libitum. The experimental design was in completely randomized blocks with seven treatments and eight replicates of 20 birds per experimental unit. Six different digestible isoleucine/lysine ratios (58.0; 62.0; 66.0; 70.0; 74.0 and $78.0 \%$ ) were assessed. Diets were formulated to meet the requirements according to Rostagno et al. (2005), except for isoleucine and lysine. In order to avoid the excess of lysine, the digestible lysine value of experimental diets was calculated to meet $89 \%$ of the requirements according to Rostagno et al. (2005) (0.900\%). A positive control (C+) treatment adequate in lysine $(1.010 \%)$ and isoleucine $(0.725 \%)$ was included in the experimental design.

With the inclusion of industrial amino acids to provide the ratios tested, the starch varied between diets to compose $100 \%$ (Table 1 ). The analyses of amino acids (Tables 2 and 3 ) were conducted through EVONIK.

In the two phases of the experiment, birds were housed in masonry shed subdivided in $1.0 \times 2.0 \mathrm{~m}$ pens (provided with bedding of wood shavings, nipple drinker and tubular feeder) with ceiling height of $3 \mathrm{~m}$, covered with asbestos tile, with ridge vents; cemented floor; side walls comprised of $0.40 \mathrm{~m}$ walls and the rest with mesh wire; and plastic curtains for the control of temperature and air currents. The management of drinkers, feeders, curtains and birds followed the recommendations of the manual for managing COBB500 broiler chickens (Cobb Vantress, 2008). Water and feed were supplied ad libitum during the experimental periods. Before the beginning of each experimental period, birds were fed branny commercial diet. The continuous lighting
Table 1 - Ingredients and calculated composition of basal diets of starter ( 7 to 21 days) and finishing (30 to 43 days) phases

\begin{tabular}{|c|c|c|}
\hline Ingredients & 7 to 21 days & 30 to 43 days \\
\hline Corn & 70.67 & 76.69 \\
\hline Soybean meal (45\%) & 9.17 & 6.28 \\
\hline Gluten meal (60\%) & 6.00 & 5.00 \\
\hline Spray-dried plasma & 3.73 & 4.00 \\
\hline Soybean oil & 0.57 & 0.54 \\
\hline Dicalcium phosphate & 1.856 & 1.524 \\
\hline Limestone & 0.981 & 0.893 \\
\hline Salt & 0.160 & 0.160 \\
\hline $\mathrm{K}_{2} \mathrm{CO}_{3}$ & 0.364 & 0.423 \\
\hline $\mathrm{NaHCO}_{3}$ & 0.300 & 0.300 \\
\hline L-lysine $\mathrm{HCl}$ (79\%) & $0.425(0.610)^{1}$ & $0.365(0.505)^{1}$ \\
\hline L-isoleucine (98.5\%) & 0.000 & 0.000 \\
\hline DL-methionine (99\%) & 0.253 & 0.215 \\
\hline L-threonine (98\%) & 0.147 & 0.100 \\
\hline Glycine & 0.439 & 0.248 \\
\hline L-arginine (98.5\%) & 0.413 & 0.358 \\
\hline L-tryptophan (98\%) & 0.030 & 0.040 \\
\hline L-valine $(98.5 \%)$ & 0.071 & 0.097 \\
\hline Choline chloride (70\%) & 0.100 & 0.100 \\
\hline Vitamins $^{2}$ & 0.050 & 0.050 \\
\hline Minerals ${ }^{3}$ & 0.100 & 0.100 \\
\hline Anticoccidial & 0.055 & 0.055 \\
\hline Antioxidant ${ }^{4}$ & 0.010 & 0.010 \\
\hline Glutamic acid & 3.000 & 2.000 \\
\hline Inert & 0.450 & 0.000 \\
\hline Starch $^{5}$ & 0.660 & 0.450 \\
\hline Total & 100.00 & 100.00 \\
\hline \multicolumn{3}{|l|}{ Calculated composition } \\
\hline Crude protein, \% & 19.99 & 17.78 \\
\hline Metabolizable energy, kcal/kg & 3150 & 3225 \\
\hline Digestible isoleucine, \% & 0.580 & 0.522 \\
\hline Digestible lysine, \% & $1.000(1.146)^{1}$ & $0.900(1.010)^{1}$ \\
\hline Digestible met + cys, $\%$ & 0.825 & 0.761 \\
\hline Digestible threonine, \% & 0.745 & 0.661 \\
\hline Digestible tryptophan, \% & 0.183 & 0.180 \\
\hline Digestible arginine, \% & 1.203 & 1.070 \\
\hline Digestible valine, \% & 0.824 & 0.800 \\
\hline $\mathrm{Ca}, \%$ & 0.884 & 0.764 \\
\hline Available $\mathrm{P}, \%$ & 0.442 & 0.380 \\
\hline $\mathrm{Na}, \%$ & 0.214 & 0.223 \\
\hline
\end{tabular}

${ }^{1}$ Control diet $(\mathrm{C}+)$.

2 Vitamin mix (kg of product): vit. A - 15,000,000 UI; vit. D3 - 1,500,000 UI; vit. E - 15,000 UI; vit. B1 - 2.0 g; vit. B2 - 4.0 g; vit. B6 - 3.0 g; vit. B12 - 0.015 g; nicotinic acid - $25 \mathrm{~g}$; pantothenic acid - $10 \mathrm{~g}$; vit. K3 - $3.0 \mathrm{~g}$; folic acid - $1.0 \mathrm{~g}$; zinc bacitracin - 10 g; selenium - 250 mg; antioxidant BHT - 10 g; excipient q.s. $1.000 \mathrm{~g}$.

${ }^{3}$ Mineral mix (kg of product): manganese - 80 g; iron - 80 g; zinc - 50 g; copper -

$10 \mathrm{~g}$; cobalt - $2 \mathrm{~g}$; iodine - $1 \mathrm{~g}$; excipient q.s. - $1.000 \mathrm{~g}$.

4 Antioxidant: BHT (butylated hydroxytoluene).

5 Variable with inclusion of L-isoleucine and L-lysine.

program (24 hours of natural + artificial light) was adopted during the whole experimental period and the heating of chicks was done with infrared light bulbs of adjustable height, set to promote the most comfort possible to birds. Records of the internal temperature of the shed were obtained with the installation of three maximum and minimum thermometers placed at different places of the facility, at the height of birds. The average temperatures recorded during the experiment were: from 7 to 21 days, $24^{\circ} \mathrm{C}\left(20\right.$ and $29^{\circ} \mathrm{C}$ 
Table 2 - Total isoleucine of experimental diets of starter phase (7 to 21 days of age)

\begin{tabular}{llrcccccc}
\hline Isoleucine & & \multicolumn{5}{c}{ Digestible isoleucine/lysine ratio (\%) } \\
\cline { 3 - 8 } & & 58.0 & 61.5 & 65.0 & 68.5 & 72.0 & 75.5 \\
\hline \multirow{2}{*}{ Total, \% } & Calculated & 0.635 & 0.671 & 0.705 & 0.741 & 0.775 & 0.811 \\
\multirow{2}{*}{ Free, \% } & Determined & 0.620 & 0.670 & 0.720 & 0.720 & 0.760 & 0.790 & 0.711 \\
& Calculated & 0.000 & 0.035 & 0.070 & 0.105 & 0.140 & 0.175 & 0.175 \\
& Determined & $<0.010$ & 0.036 & 0.073 & 0.108 & 0.141 & 0.167 & 0.173 \\
\hline
\end{tabular}

Table 3 - Total isoleucine of experimental diets of finishing phase (30 to 43 days of age)

\begin{tabular}{llrcccccc}
\hline Isoleucine & & \multicolumn{5}{c}{ Digestible isoleucine/lysine ratio (\%) } \\
\cline { 3 - 8 } & & 58.0 & 62.0 & 66.0 & 70.0 & 74.0 & 78.0 \\
\hline \multirow{2}{*}{ Total, \% } & Calculated & 0.573 & 0.609 & 0.644 & 0.681 & 0.716 & 0.753 & 0.753 \\
& Determined & 0.570 & 0.610 & 0.650 & 0.680 & 0.710 & 0.750 & 0.750 \\
\multirow{2}{*}{ Free, \% } & Calculated & 0.000 & 0.036 & 0.072 & 0.108 & 0.144 & 0.180 & 0.180 \\
& Determined & $<0.010$ & 0.042 & 0.072 & 0.110 & 0.134 & 0.187 & 0.187 \\
\hline
\end{tabular}

C+ - positive control.

minimum and maximum, respectively); and from 30 to 43 days, $22{ }^{\circ} \mathrm{C}$ (17 and $26{ }^{\circ} \mathrm{C}$ minimum and maximum, respectively).

Birds and diets were weighed at the beginning and end of each experimental period ( 7 to 21 days and 30 to 43 days) for the calculation of the following parameters: feed intake, weight gain and feed conversion. Mortality was recorded daily for the feed intake in the two phases to be corrected. Feed conversion was corrected to mortality and represented in grams of feed ingested per all live birds present in the pen divided by grams of weight per pen. In the starter phase, three birds with the average weight of every pen were slaughtered at 21 days for evaluation of carcass characteristics such as breast and breast yield in relation to live weight. In the finishing phase, three birds with the average weight of each pen were slaughtered at 44 days for evaluation of carcass yield, abdominal fat, breast, breast yield, thigh and drumstick.

Statistical analyses were conducted through the software SAEG (Sistema para Análises Estatísticas e Genéticas, version 9.1). Variance analysis and Dunnett test $(\mathrm{P}<0.05)$ were utilized for the contrast between treatment control and the different ratios. Regression analysis was conducted for the different ratios. For the response variables which presented quadratic behavior, the inflection point was calculated, as the best ratios and $95 \%$ of these values as confidence (Sakomura \& Rostagno, 2007). The Linear Response Plateau (LRP) was utilized for response variables that presented significant quadratic effect in the regression analysis. The data were also adjusted by the quadratic model associated to the plateau for the variables which presented significant quadratic effect, inserting the plateau (y) in the quadratic equation. The recommendations of best ratio for each phase were obtained through the average of the different response variables in face of the different analyses, in function of the good adjustment of the data to them.

\section{Results and Discussion}

Analyzing the results (Table 4), one can observe that broiler chickens fed the diet containing digestible isoleucine/lysine ratio of $58 \%$ showed worse $(\mathrm{P}<0.05)$ weight gain and feed conversion when compared with treatment control, and broilers which received the ratio of $75.5 \%$, only weight gain. The other ratios were significantly similar $(\mathrm{P}>0.05)$ to the treatment control, indicating the possibility of meeting the digestible isoleucine/lysine ratio between the values of $61.5 \%$ and $72 \%$.

Table 4 - Feed intake(FI), weight gain(WG) and feed conversion (FC) of broiler chickens fed diets containing different digestible isoleucine/lysine ratios during the starter phase ( 7 to 21 days)

\begin{tabular}{lccc}
\hline Ratio (\%) & FI (g/bird) & WG (g/bird) & FC \\
\hline C+ & 1000 & $707 \mathrm{a}$ & $1.416 \mathrm{a}$ \\
58.0 & 984 & $653 \mathrm{~b}$ & $1.506 \mathrm{~b}$ \\
61.5 & 1002 & $695 \mathrm{a}$ & $1.441 \mathrm{a}$ \\
65.0 & 998 & $696 \mathrm{a}$ & $1.434 \mathrm{a}$ \\
68.5 & 1011 & $707 \mathrm{a}$ & $1.431 \mathrm{a}$ \\
72.0 & 998 & $698 \mathrm{a}$ & $1.432 \mathrm{a}$ \\
75.5 & 998 & $686 \mathrm{~b}$ & $1.455 \mathrm{a}$ \\
& & ANOVA - regression & \\
Quadratic & $\mathrm{ns}^{1}$ & 0.001 & 0.001 \\
CV (\%) & 2.58 & 3.20 & 1.55 \\
\hline
\end{tabular}

a,b - means with different letters in the same row are significantly different from treatment positive control $(\mathrm{C}+)$ by the Dunnett test $(\mathrm{P}<0.05)$.

${ }^{1}$ Non-significant $(\mathrm{P}>0.05)$ 
For the regression analysis in the starter phase, there was no significant difference $(\mathrm{P}>0.05)$ in feed intake; however, quadratic effect $(\mathrm{P}<0.05)$ was observed for weight gain (WG - 1368.53 + 60.6357Iso - 0.443013Iso ${ }^{2}$; $\mathrm{R}^{2}=0.90$ ) (Figure 1$)$ and for feed conversion ( $\mathrm{FC}=4.6459$ -0.0941626 Iso + 0.000687838Iso ${ }^{2} ; \mathrm{R}^{2}=0.91$ ) (Figure 2); optimum ratios were of 68 and $68 \%$, respectively. By applying a confidence limit of $95 \%$ for the response of the quadratic equation for weight gain and for feed conversion one gets the optimum relation of $65 \%$ for both. At the LRP analysis for weight gain, best ratio of $62 \%$ was obtained with plateau at $697 \mathrm{~g}\left(\mathrm{WG}=-43.0+12.0 \mathrm{Iso} ; \mathrm{R}^{2}=1.00\right)$ (Figure 1$)$ and for feed conversion, the ratio of $62 \%$ with plateau at 1.438 $\left(\mathrm{FC}=2.583143-0.018571\right.$ Iso; $\left.\mathrm{R}^{2}=1.00\right)$ (Figure 2). By applying the quadratic analysis with plateau, one obtains best ratio of $64 \%$ for both parameters.

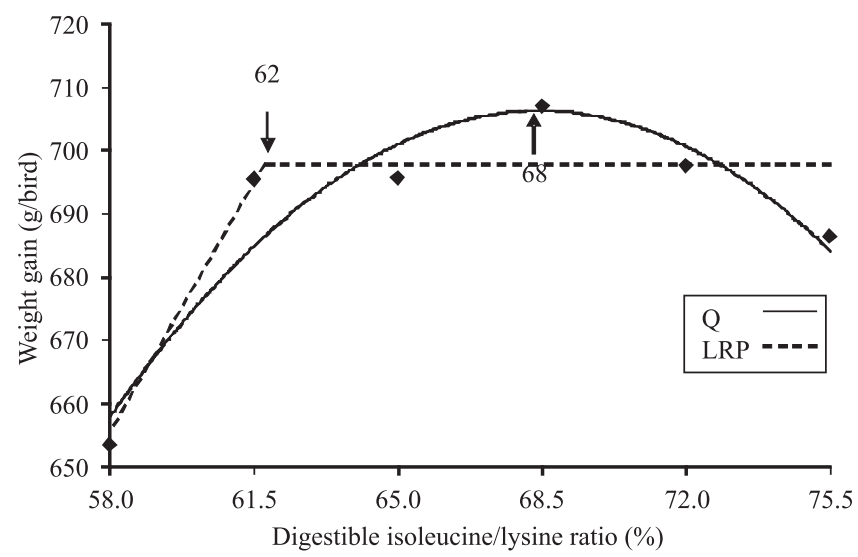

Figure 1 - Effect of different digestible isoleucine/lysine ratio in the diet on the weight gain of broiler chickens in the phase from 7 to 21 days.

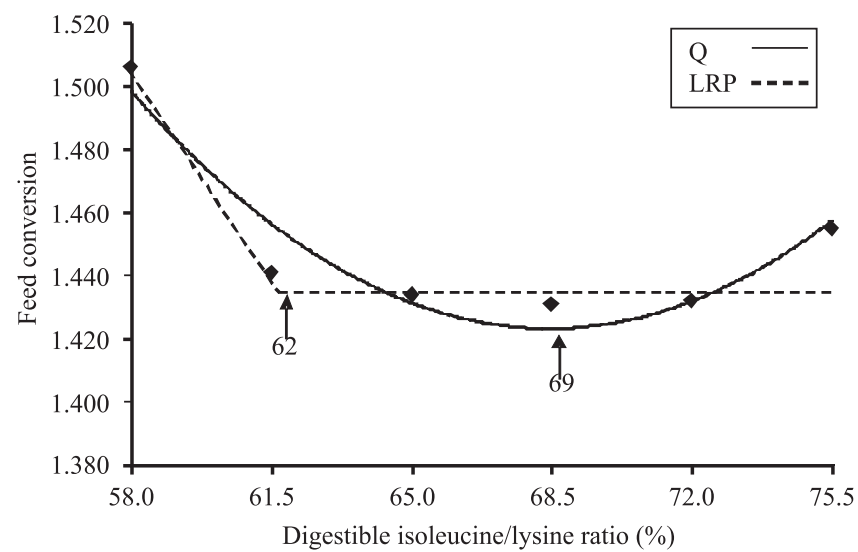

Figure 2 - Effect of different digestible isoleucine/lysine ratio in the diet on the feed conversion of broiler chickens in the phase from 7 to 21 days.
Table 5 - Breast (B), breast yield (BY), breast fillet (F), breast fillet yield (FY) of broiler chickens fed diets containing different digestible isoleucine/lysine ratios during the starter phase ( 7 to 21 days) and slaughtered at 21 days of age

\begin{tabular}{lcccc}
\hline Ratio (\%) & B (g) & BY (\%) & F (g) & FY (\%) \\
\hline C+ & $183 \mathrm{a}$ & $20.71 \mathrm{a}$ & $147 \mathrm{a}$ & $16.69 \mathrm{a}$ \\
58.0 & $150 \mathrm{~b}$ & $18.30 \mathrm{~b}$ & $118 \mathrm{~b}$ & $14.37 \mathrm{~b}$ \\
61.5 & $168 \mathrm{~b}$ & $19.49 \mathrm{~b}$ & $132 \mathrm{~b}$ & $15.37 \mathrm{~b}$ \\
65.0 & $168 \mathrm{~b}$ & $19.55 \mathrm{~b}$ & $135 \mathrm{~b}$ & $15.73 \mathrm{~b}$ \\
68.5 & $173 \mathrm{~b}$ & $19.70 \mathrm{~b}$ & $138 \mathrm{~b}$ & $15.74 \mathrm{~b}$ \\
72.0 & $170 \mathrm{~b}$ & $19.73 \mathrm{~b}$ & $135 \mathrm{~b}$ & $15.72 \mathrm{~b}$ \\
75.5 & $168 \mathrm{~b}$ & $19.70 \mathrm{~b}$ & $134 \mathrm{~b}$ & $15.75 \mathrm{~b}$ \\
& & ANOVA & & \\
Quadratic & 0.001 & 0.005 & 0.001 & 0.002 \\
CV (\%) & 4.78 & 3.34 & 5.03 & 3.87 \\
\hline
\end{tabular}

a,b Means with different letters in the same column are significant different from treatment positive control $(\mathrm{C}+)$ by the Dunnett test $(\mathrm{P}<0.05)$.

Due to the meeting of the digestible lysine requirement for the starter phase (Table 5), birds fed the diet control presented better $(\mathrm{P}<0.05)$ weight and breast yield and fillet yield when compared with birds fed diets containing different digestible isoleucine/lysine ratios and suboptimum lysine level.

For the regression analysis, quadratic effect was observed $(\mathrm{B}<0.05)$ for breast weight $(\mathrm{B}=-592.795+$ 22.0915Iso -0.159439 Iso $^{2} ; \mathrm{R}^{2}=0.88$ ) (Figure 3 ), breast yield $\left(B Y=-24.9433+1.27411\right.$ Iso -0.00906046 Iso $\left.^{2} ; R^{2}=0.88\right)$ (Figure 4), breast fillet weight $(\mathrm{F}=-563.471+20.235$ Iso $0.145955 \mathrm{Iso}^{2} ; \mathrm{R}^{2}=0.92$ ) (Figure 5) and breast fillet yield $\left(F Y=-30.8103+1.33092\right.$ Iso -0.00948617 Iso $\left.^{2} ; R^{2}=0.92\right)$ (Figure 6), with optimum ratios of 69, 70, 69 and 70\%, respectively. By applying confidence limit of $95 \%$ for the response of the quadratic equation to weight and yield of both parameters evaluated, one obtains optimum ratios of 66 and 67\%, respectively. At the LBY analysis for breast weight, best ratio of $62 \%$ was obtained with plateau at $169 \mathrm{~g}$ $\left(B=5.142857-148.285714\right.$ Iso; $\left.R^{2}=1.00\right)$ (Figure 3$)$, for breast yield, best ratio of $62 \%$ was obtained with plateau at $19.67 \%\left(B Y=-1.42+0.34\right.$ Iso; $\left.R^{2}=1.00\right)$ (Figure 4$)$, for breast fillet weight, $62 \%$ with plateau at $135 \mathrm{~g}(\mathrm{~F}=4.0-114.0 \mathrm{Iso}$; $\mathrm{R}^{2}=1.00$ ) (Figure 5) and for breast fillet yield, ratio of $63 \%$ with plateau at $15.71 \%$ (FY $=-2.201429+0.285714$ Iso; $\mathrm{R}^{2}=1.00$ ) (Figure 6). By applying quadratic analysis with plateau, the best ratios for weight and yield of both parameters assessed are 65 and $66 \%$, respectively.

In the literature, it is possible to observe different recommendations of digestible isoleucine/lysine ratios for broilers at the starter phase. According to Baker et al. (2002), the complexity in establishing accurate ratios for amino acids lies in the possibilities of variable responses to be utilized (such as weight gain and feed conversion) and the 


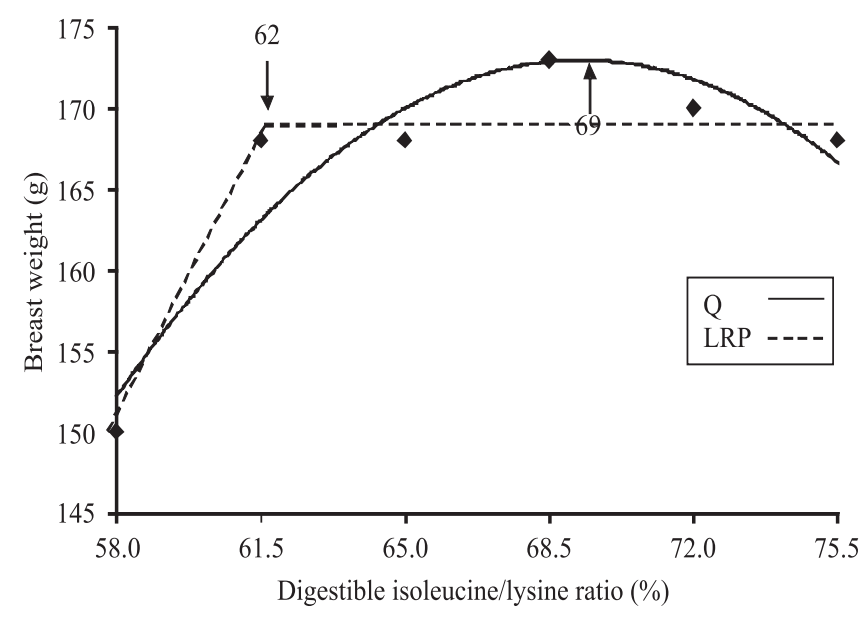

Figure 3 - Effect of different digestible isoleucine/lysine ratios in the diet on the breast weight of broiler chickens slaughtered at 21 days of age.

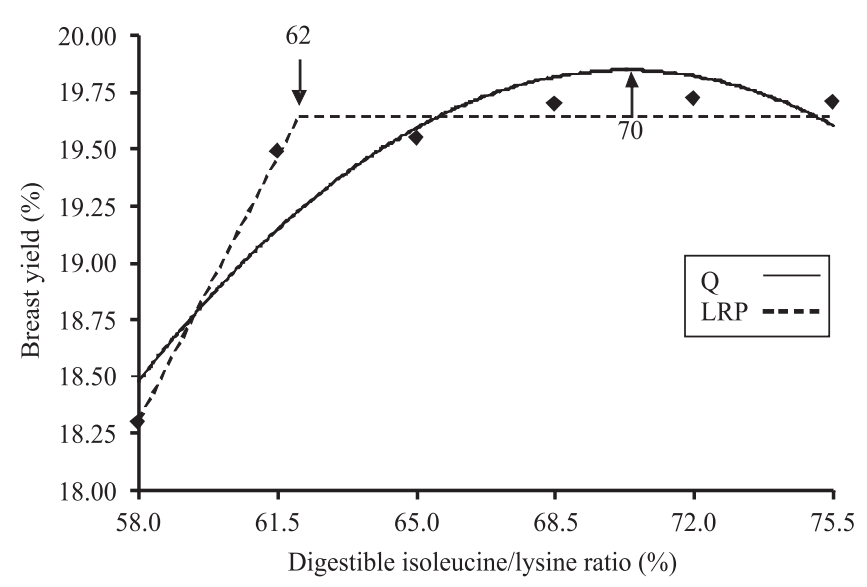

Figure 4 - Effect of different digestible isoleucine/lysine ratios in the diet on the breast yield of broiler chickens slaughtered at 21 days of age.

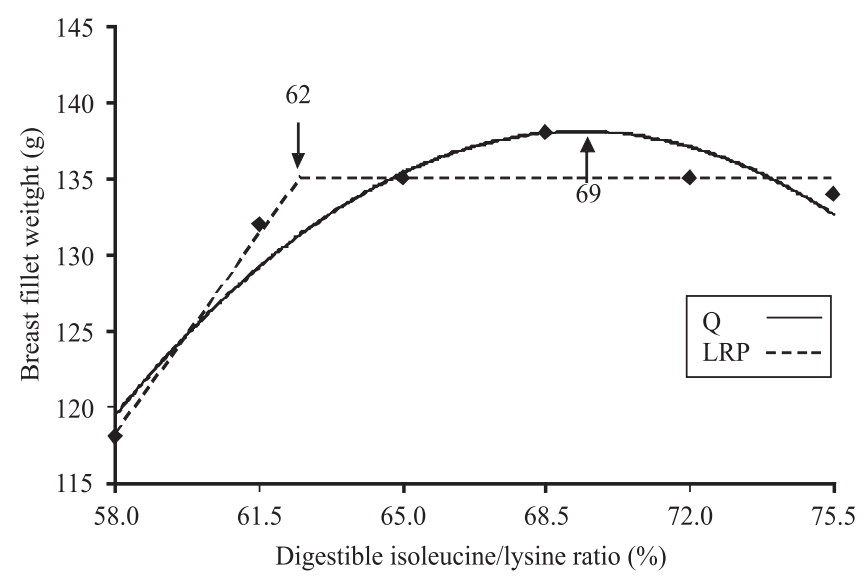

Figure 5 - Effect of different digestible isoleucine/lysine ratios in the diet on the breast fillet weight of broiler chickens slaughtered at 21 days of age.

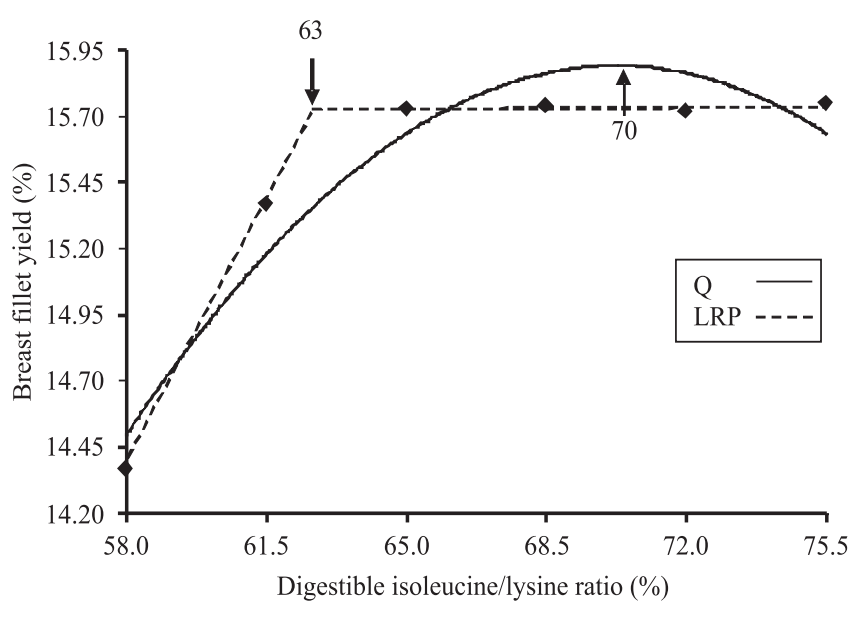

Figure 6 - Effect of different digestible isoleucine/lysine ratios in the diet on the breast fillet yield of broiler chickens slaughtered at 21 days of age.

statistical analyses that can be carried out. The quadratic one is known for overestimating the ratios, which represents damage and increase in the environmental pollution due to greater nitrogen excretion by animals, whereas the LRP is known for underestimating them, so it can reduce animal performance. Baker et al. (2002) utilized the quadratic analysis as plateau and demonstrated it as a possibility at the determination of the ratios for amino acids, once the values obtained were close to the confidence limit of $90 \%$ of the values obtained in the quadratic analysis, although most researchers adopt $95 \%$ of the quadratic one (Sakomura \& Rostagno, 2007).

Through the results obtained from the different variables herein studied, the recommendation for the digestible isoleucine/lysine ratio, which meets the main productive parameters of broilers in the phase from 7 to 21 days, is $66 \%$, which is a value close to the recommended by Rostagno et al. (2011), of 67\%. However, Baker et al. (2002) concluded that $61.4 \%$ is the best isoleucine/lysine ratio for the starter phase (08 to 21 days) based on the LRP of weight gain and feed conversion, which is inferior to the value recommended by Baker (1997), of 67\%. In a literature review, Sá \& Nogueira (2010) observed as average of several studies, the ratio of $66.6 \%$ digestible isoleucine/lysine for broiler chickens from 08 to 21 days of age.

Kidd et al. (2004) recommended 6.7 to $7.1 \mathrm{~g} / \mathrm{kg}$ isoleucine for broiler chickens from 18 to 30 days of age, which are values inferior to the $8.10 \mathrm{~g} / \mathrm{kg}$ isoleucine in the diet obtained with the conversion of the result from the present study.

Analyzing the results for the finishing phase (Table 6), one can observe that broilers fed diets containing different digestible isoleucine/lysine ratios presented worse $(\mathrm{P}<0.05)$ feed conversion when compared with those fed the diet 
Table 6 - Feed intake(FI), weight gain(WG) and feed conversion (FC) of broiler chickens fed different digestible isoleucine/lysine ratios during the finishing phase (30 to 43 days)

\begin{tabular}{lccc}
\hline Ratio (\%) & FI (g/bird) & WG (g/bird) & FC \\
\hline $\mathrm{C}+$ & 2499 & $1366 \mathrm{a}$ & $1.830 \mathrm{a}$ \\
58 & 2403 & $1210 \mathrm{~b}$ & $1.988 \mathrm{~b}$ \\
62 & 2499 & $1290 \mathrm{~b}$ & $1.939 \mathrm{~b}$ \\
66 & 2499 & $1304 \mathrm{~b}$ & $1.917 \mathrm{~b}$ \\
70 & 2515 & $1330 \mathrm{a}$ & $1.892 \mathrm{~b}$ \\
74 & 2476 & $1314 \mathrm{a}$ & $1.884 \mathrm{~b}$ \\
78 & 2482 & $1317 \mathrm{a}$ & $1.886 \mathrm{~b}$ \\
& & ANOVA - regression & \\
Quadratic & 0.021 & 0.006 & 0.007 \\
CV (\%) & 3.15 & 4.13 & 1.75 \\
\hline
\end{tabular}

Means with different letters on the same column are significantly different from treatment positive control $(\mathrm{C}+)$ by the Dunnett test $(\mathrm{P}<0.05)$.

control, so it was possible to infer that this is an effect of the sub-optimum level of lysine employed; nevertheless, for weight gain, the ratios of 70, 74 and $78 \%$ were significantly similar $(\mathrm{P}>0.05)$ to control, indicating the possibility of meeting of the best digestible isoleucine/lysine ratio close to these values.

For the regression analysis, quadratic effect $(\mathrm{P}<0.05)$ was observed for feed intake ( FI $=-795.78+94.7991$ Iso 0.679058 Iso $^{2} ; \mathrm{R}^{2}=0.76$ ) (Figure 7 ), weight gain $(\mathrm{WG}=$ $-1592.88+81.1666$ Iso -0.563571 Iso $\left.^{2} ; R^{2}=0.93\right)$ (Figure 8 ) and feed conversion ( $\mathrm{FC}=3.825832-0.0516222$ Iso + 0.000343034 Iso $^{2} ; R^{2}=0.99$ ) (Figure 9); optimum ratios were 70,72 and $75 \%$, respectively. By utilizing the confidence limit of $95 \%$ for the response of the quadratic equation to feed intake, weight gain and feed conversion, the optimum ratios are 66,68 and $72 \%$, respectively. At the LRP analysis for feed intake, best ratio of $62 \%$ was obtained with plateau at $2493 \mathrm{~g}\left(\mathrm{FI}=1011.0+24.0\right.$ Iso; $\left.\mathrm{R}^{2}=1.00\right)($ Figure 7$)$, for weight gain, it was $63 \%$ with plateau at $1316 \mathrm{~g}(\mathrm{WG}=50.0+$ 20.0Iso; $\mathrm{R}^{2}=1.00$ ) (Figure 8 ) and for feed conversion, the ratio of $69 \%$ with plateau at $1.888(\mathrm{FC}=-0.00883493+$ 2.49557XIso; $R^{2}=0.91$ ) (Figure 9). By applying quadratic analysis with plateau, the best ratios for feed intake, weight gain and feed conversion were 64,68 and $72 \%$, respectively.

For the carcass parameters evaluated in the finishing phase (Table 7), there was no significant effect $(\mathrm{P}>0.05)$ of the different digestible isoleucine/lysine ratios evaluated. Through the present study, it is possible to infer that the isoleucine requirement for the carcass parameters assessed at 44 days is lower than the requirement for performance.

Through the results obtained in the different variables studied in the present study, the recommendation for the digestible isoleucine/lysine ratio which meets the main productive parameters for broilers in the phase from 30 to 43 days is $68 \%$, and this is the same value recommended by

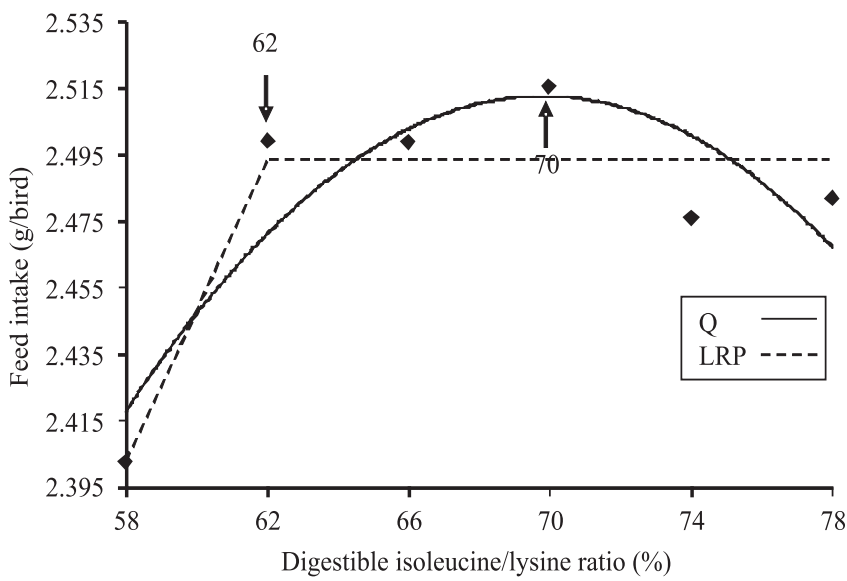

Figure 7 - Effect of different digestible isoleucine/lysine ratios in the diet on the feed intake of broiler chickens in the phase from 30 to 43 days of age.

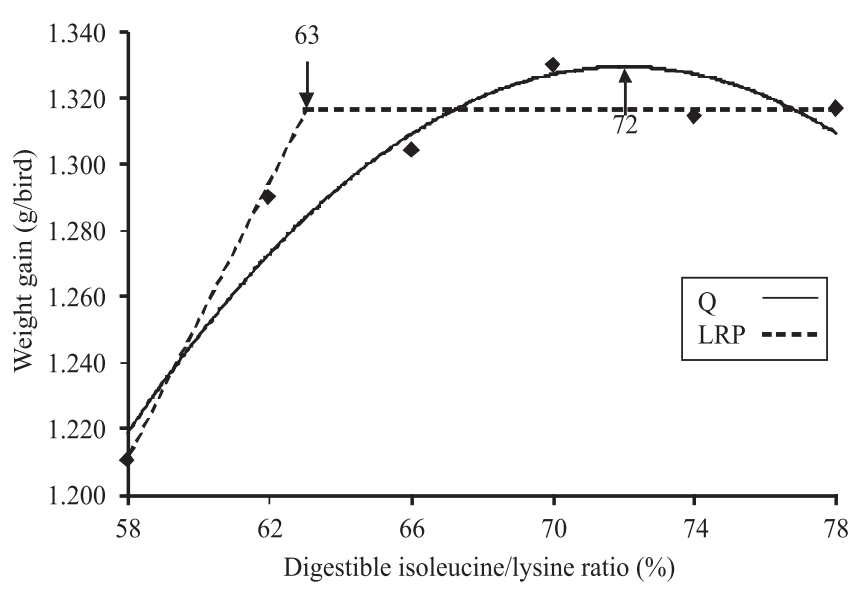

Figure 8 - Effect of different digestible isoleucine/lysine ratios in the diet on the weight gain of broiler chickens in the phase from 30 to 43 days of age.

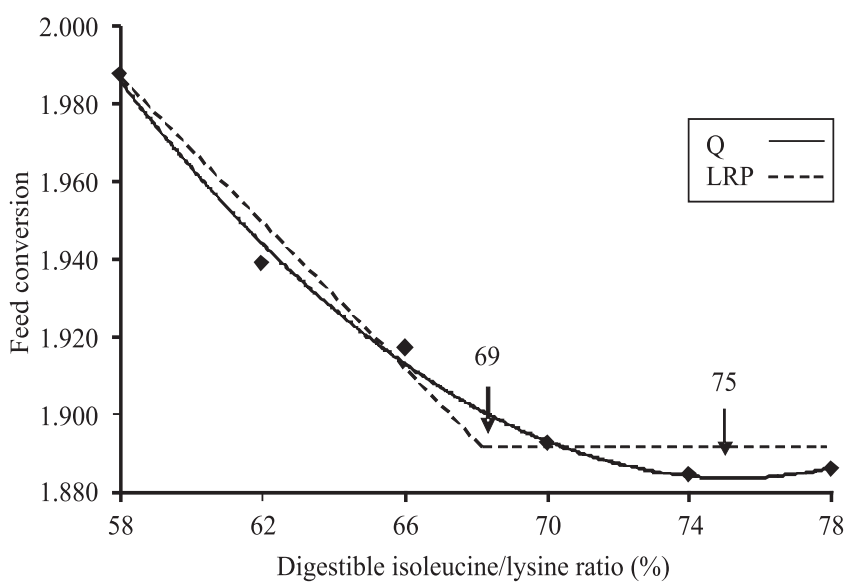

Figure 9 - Effect of different digestible isoleucine/lysine ratios in the diet on the feed conversion of broiler chickens in the phase from 30 to 43 days of age.

R. Bras. Zootec., v.41, n.7, p.1699-1705, 2012 
Table 7 - Effect of different digestible isoleucine/lysine ratios on carcass (C), abdominal fat (AF), breast (B), breast fillet (F) and thigh and drumstick (TD) of broilers slaughtered at 44 days of age

\begin{tabular}{|c|c|c|c|c|c|c|c|c|c|c|}
\hline \multirow[t]{2}{*}{ Ratio (\%) } & \multicolumn{2}{|c|}{$\mathrm{C}$} & \multicolumn{2}{|c|}{$\mathrm{AF}$} & \multicolumn{2}{|c|}{ B } & \multicolumn{2}{|c|}{$\mathrm{F}$} & \multicolumn{2}{|c|}{ T D } \\
\hline & (g) & $(\%)$ & (g) & $(\%)$ & (g) & $(\%)$ & (g) & $(\%)$ & (g) & $(\%)$ \\
\hline $\mathrm{C}+$ & $2156 a$ & 72.49 & 40 & 1.87 & $775 a$ & 35.95 & $604 a$ & $28.03 \mathrm{a}$ & 617 & 28.65 \\
\hline 58 & $2023 b$ & 71.75 & 41 & 2.04 & $702 b$ & 34.73 & $537 b$ & $26.53 b$ & 593 & 29.35 \\
\hline 62 & $2076 b$ & 71.82 & 44 & 2.13 & $729 b$ & 35.11 & $562 b$ & $27.07 \mathrm{a}$ & 604 & 29.12 \\
\hline 66 & $2107 a$ & 72.49 & 41 & 1.94 & $744 a$ & 35.33 & $571 b$ & $27.08 \mathrm{a}$ & 615 & 29.20 \\
\hline 70 & $2109 a$ & 71.96 & 45 & 2.16 & $741 \mathrm{a}$ & 35.13 & $571 b$ & $27.10 \mathrm{a}$ & 605 & 28.72 \\
\hline 74 & $2125 a$ & 73.11 & 51 & 2.40 & $745 a$ & 35.08 & $569 b$ & $26.81 \mathrm{a}$ & 614 & 28.90 \\
\hline 78 & $2106 a$ & 72.15 & 47 & 2.24 & $752 \mathrm{a}$ & 35.71 & $579 a$ & $27.53 a$ & 607 & 28.83 \\
\hline & & & & & ANOV & & & & & \\
\hline Regression & $\mathrm{ns}^{1}$ & ns & ns & ns & ns & ns & ns & ns & ns & ns \\
\hline CV (\%) & 2.57 & 1.79 & 18.00 & 18.89 & 4.56 & 3.21 & 4.84 & 4.26 & 3.67 & 3.05 \\
\hline
\end{tabular}

Means with different letters in the same column are significantly different from treatment positive control $(\mathrm{C}+)$ by the Dunnett test $(\mathrm{P}<0.05)$.

1 Non-significant $(\mathrm{P}>0.05)$.

Rostagno et al. (2011). Campos et al. (2009) concluded that $70 \%$ is the best digestible isoleucine/lysine ratio for this phase. In a literature review, Sá \& Nogueira (2010) observed the ratios of $67.1 \%$ and $69.5 \%$ digestible isoleucine/lysine for broiler chickens in the phases from 22 to 35 and 35 to 42 days of age as average of different studies.

\section{Conclusions}

The isoleucine requirement for the carcass parameters evaluated at 44 days is lower than the requirement for performance. The digestible isoleucine/lysine ratio recommended for broiler chickens at the starter phase ( 7 to 21 days) is $66 \%$ and at the finishing phase (30 to 43 ), $68 \%$.

\section{Acknowledgements}

To EVONIK - Degussa for financing the project and to Capes and CNPq for the fellowships granted.

\section{References}

BAKER, D.H. Ideal amino acid profiles for swine and poultry and their applications in feed formulation. Biokyowa Technical Review, v.9, p.1-24, 1997.

BAKER, D.H.; BATAL, A.B.; PARR, T.M. et al. Ideal ratio (relative to lysine) of tryptophan, threonine, isoleucine, and valine for chicks during the second and third weeks Posthatch. Poultry Science, v.81, n.4, p.485-494, 2002.
CAMPos, A.M.A.; NOGUEIRA, E.T.; ALBINO, L.F.T. et al. Effects of digestible isoleucine:lysine ratios on broiler performance and breast yield. In: EUROPEAN CONFERENCE TOURS, 13., 2010, Paris. Anais... Paris: The World's Poultry Science Association, 2009. (CD-ROM).

COBB-VANTRESS. Manual de manejo de frangos de corte. Guapiaçu: Cobb Vantress, 2008. 66p.

KIDD, M.T.; BURNHAM, D.J.; KERR, B.J. Dietary isoleucine responses in male broiler chickens. British Poultry Science, v.45, n.1, p.67-75, 2004.

LECLERCQ, B. El concepto de proteina ideal y el uso de aminoácidos sinteticos estudio comparativo entre pollos y cerdos. In: CURSO DE ESPECIALIZACIÓN FEDNA: avances en nutrición y alimentación animal, 14., 1998, Madrid. Anais... Madrid: Fundación Española para el Desarrollo de la Nutrición Animal, 1998a. p.191-202.

LECLERCQ, B. Specific effects of lysine on broiler production: Comparison with threonine and valine. Poultry Science, v.77, n.1, p.118-123, 1998b.

PARK, B.C.; AUSTIC, R.E. Isoleucine imbalance using selected mixtures of imbalancing amino acids in diets of the broiler chick. Poultry Science, v.79, n.12, p.1782-1789, 2000.

ROSTAGNO, H.S.; ALBINO, L.F.T.; DONZELE, J.L. et al. Tabelas brasileiras para aves e suínos - Composição de alimentos e exigências nutricionais. 2.ed. Viçosa, MG, 2005. $186 \mathrm{p}$.

ROSTAGNO, H.S.; ALBINO, L.F.T.; DONZELE, J.L. et al. Tabelas Brasileiras para Aves e Suínos - Composição de alimentos e exigências nutricionais. 3.ed. Viçosa, MG, 2011. $252 \mathrm{p}$.

SÁ, L.; NOGUEIRA, E.T. [2010]. Atualização das relações valina e isoleucina com a lisina na proteína ideal para frangos de corte e suínos. Available at: <http://www.lisina.com.br/upload/ Relatorio\%20T\%C3\%A9cnico_Rel\%20Val\%20e\%20Iso\%20 com\%20Lys_2010.pdf> Accessed on: Sept. 22, 2010.

SAKOMURA, N.K.; ROSTAGNO, H.S. Métodos de pesquisa em nutrição de monogástricos. Jaboticabal: Funep, 2007. $283 p$. 